\title{
Zirconocene dipicolinate and related dicarboxylate complexes: coordination geometries and reactivities
}

\author{
Uwe Niemann, Josef Diebold, Carsten Troll, Ursula Rief and Hans-Herbert Brintzinger \\ Fakultät für Chemie, Universität Konstanz, Postfach 5560, 7750 Konstanz (Germany)
}

\begin{abstract}
Monomeric zirconocene dipicolinate complexes, which have a formal 18-electron configuration, are stable towards water and relatively inert against aqueous $\mathrm{HCl}$. Methylmagnesium chloride attacks these complexes at the dipicolinate carboxyl groups and subsequent reaction with aqueous $\mathrm{HCl}$ gives 2,6-diacetyl pyridine and the zirconocene dichloride. Other dicarboxylates, such as 3,4-dimethoxyfurane-2,5-dicarboxylate or isophthalate, form binuclear zirconocene complexes, in which one bidentate and one monodentate carboxylate ligand generate a formal 18-electron configuration. These complexes react with methylmagnesium chloride to give the respective zirconocene dimethyl complexes, i.e. by normal replacement of $\mathrm{C}=\mathrm{O}$ bonds by $\mathrm{C}-\mathrm{CH}_{3}$ bonds.
\end{abstract}

\section{Introduction}

Tetracoordinate zirconocene derivatives of the general type $\mathrm{Cp}_{2} \mathrm{ZrX}_{2}$, which have a formal 16-electron configuration, are quite labile against ligand substitution; halide, carboxylate or aroxylate ligands $\mathrm{X}$ are usually quite easily displaced from the zirconium centre, e.g. by alkyl groups from lithium, magnesium or aluminium alkyl reagents ( $c f$. eqn. (1)). While this facile ligand exchange is of great value for many synthetic and catalytic applications, more inert zirconocene derivatives might occasionally be needed. It would thus be of interest to establish in which way different coordination geometries affect the rate and course of ligand substitutions of a zirconocene derivative.

$\mathrm{Cp}_{2} \mathrm{ZrX}_{2}+2 \mathrm{RM} \longrightarrow \mathrm{Cp}_{2} \mathrm{ZrR}_{2}+2 \mathrm{XM}$

$\mathrm{X}=\mathrm{Hal}, \mathrm{R}^{\prime} \mathrm{COO}$, ArO

$\mathrm{RM}=\mathrm{CH}_{3} \mathrm{Li}, \mathrm{CH}_{3} \mathrm{MgCl},\left(\mathrm{CH}_{3}\right)_{x} \mathrm{AlCl}_{3-x}$

Decreased susceptibility towards nucleophilic substitution at the $\mathrm{Zr}$ centre is expected for pentacoordinate zirconocene derivatives of the general type $\mathrm{Cp}_{2} \mathrm{ZrX}_{2} \mathrm{~L}$ ( $\mathrm{L}=$ neutral ligand or chelate ligand atom), which have a formal 18-electron configuration. Some time ago we

Correspondence to: Prof. Dr. H.-H. Brintzinger. observed that titanocenes complexed with the tridentate ligand pyridine-2,6-dicarboxylate (dipicolinate, DIPIC) are rather inert towards ligand substitutions [1]. We have now investigated a number of zirconocene dipicolinate and related dicarboxylate complexes in order to ascertain whether the generally more open zirconocene geometry still affords similarly inert species.

\section{Results and discussion}

\subsection{Syntheses and structural characterizations}

The zirconocene dipicolinate complexes $\left(\mathrm{C}_{5} \mathrm{H}_{5}\right)_{2} \mathrm{Zr}$ (DIPIC) (1) and $\left(\mathrm{CH}_{3} \mathrm{C}_{5} \mathrm{H}_{4}\right)_{2} \mathrm{Zr}$ (DIPIC) (2), the tetramethylethano-bridged complex $\left(\mathrm{CH}_{3}\right)_{4} \mathrm{C}_{2}\left(\mathrm{C}_{5} \mathrm{H}_{4}\right)_{2}$ $\mathrm{Zr}(\mathrm{DIPIC})$ (3) and the chiral complexes rac$\mathrm{C}_{2} \mathrm{H}_{4}\left(4,5,6,7\right.$-tetrahydro-1-indenyl) ${ }_{2} \mathrm{Zr}$ (DIPIC) (4) and rac- $\left(\mathrm{CH}_{3}\right)_{2} \mathrm{Si}\left(2 \text {-methyl-4- }{ }^{\mathrm{t}} \text { butyl-1- } \mathrm{C}_{5} \mathrm{H}_{2}\right)_{2} \mathrm{Zr}$ (DIPIC) (5) were prepared either via the respective dimethylzirconocenes (method A) or from the dichlorozirconocene complexes by treatment with dipicolinic acid and trimethylamine in toluene (method B). With 3,4dimethoxyfuran-2,5-dicarboxylic acid (DIFUR), either method $A$ or $B$ gave the complexes $\left[\left(\mathrm{CH}_{3} \mathrm{C}_{5} \mathrm{H}_{4}\right)_{2} \mathrm{Zr}\right.$ (DIFUR) $]_{2}(6),\left[\left(\mathrm{CH}_{3}\right)_{4} \mathrm{C}_{2}\left(\mathrm{C}_{5} \mathrm{H}_{4}\right)_{2} \mathrm{Zr} \text { (DIFUR) }\right]_{2}$ (7) and $\left[\mathrm{C}_{2} \mathrm{H}_{4}\left(4,5,6,7 \text {-tetrahydro-1-indenyl) }{ }_{2} \mathrm{Zr} \text { (DIFUR) }\right]_{2}\right.$ (8), for all of which a dimeric structure is indicated by their mass spectra. A dimer $\left[\left(\mathrm{CH}_{3} \mathrm{C}_{5} \mathrm{H}_{4}\right)_{2} \mathrm{Zr}(\mathrm{IPHTH})\right]_{2}$ (9) 


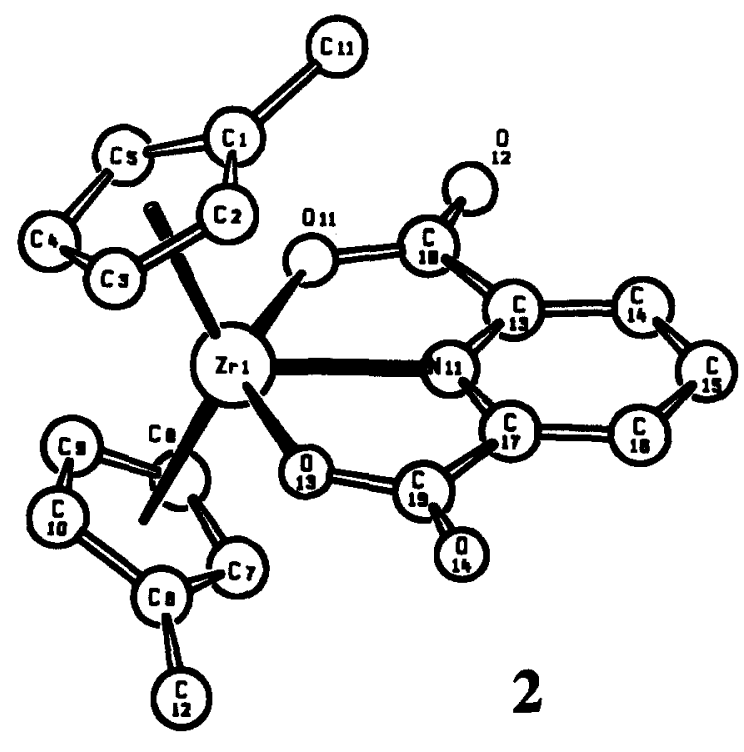

Fig. 1. Crystal structures of complexes 2 (left) and 4 (right).

is also formed with isophthalic acid (IPHTH). Compounds 1-9 were characterized by ${ }^{1} \mathrm{H}$ NMR and mass spectra and elemental analyses.

The crystal structures of the dipicolinate complexes 2 and 4 (Fig. 1, Table 1) confirm their mononuclear

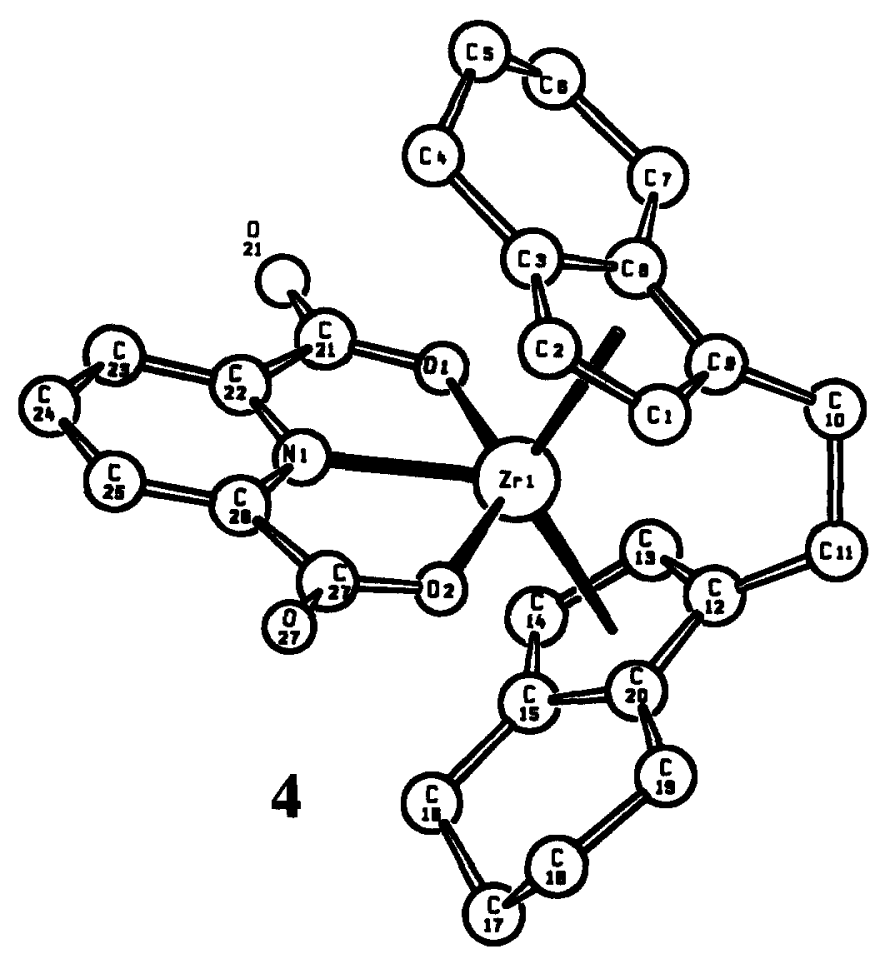

nature and the tridentate geometry of their DIPIC ligands. In this regard the dipicolinate complexes are analogous to their titanocene congeners [1] and to a zirconocene oxidiacetate (OXIDA) complex $\left(\mathrm{C}_{5} \mathrm{H}_{5}\right)_{2^{-}}$ $\mathrm{Zr}$ (OXIDA) recently described by Thewalt and

TABLE 1. Selected distances (pm) and angles $\left(^{\circ}\right)$ for complexes 2 and 4

\begin{tabular}{|c|c|c|c|}
\hline & 2 & & 4 \\
\hline $\mathrm{Zr}(1)-\mathrm{N}(1)$ & $231.0(2)$ & $\mathrm{Zr}(1)-\mathrm{N}(1)$ & $231.4(5)$ \\
\hline $\mathrm{Zr}(1)-\mathrm{O}(1)$ & $218.1(2)$ & $\mathrm{Zr}(1)-\mathrm{O}(1)$ & $217.7(4)$ \\
\hline $\mathrm{Zr}(1)-\mathrm{O}(3)$ & $218.0(2)$ & $\operatorname{Zr}(1)-O(2)$ & $218.2(3)$ \\
\hline $\operatorname{Zr}(1)-C(1)$ & $259.7(3)$ & $\operatorname{Zr}(1)-C(1)$ & $243.4(6)$ \\
\hline $\mathrm{Zr}(1)-\mathrm{C}(2)$ & $254.2(3)$ & $\mathrm{Zr}(1)-\mathrm{C}(2)$ & $249.7(6)$ \\
\hline $\mathrm{Zr}(1)-\mathrm{C}(3)$ & $251.8(4)$ & $\operatorname{Zr}(1)-C(3)$ & $259.4(6)$ \\
\hline $\mathrm{Zr}(1)-C(4)$ & $246.3(3)$ & $\mathrm{Zr}(1)-\mathrm{C}(8)$ & $259.2(7)$ \\
\hline $\operatorname{Zr}(1)-C(5)$ & $250.7(3)$ & $\operatorname{Zr}(1)-C(9)$ & $251.5(6)$ \\
\hline $\mathrm{Zr}(1)-C(6)$ & $256.8(3)$ & $\operatorname{Zr}(1)-C(12)$ & $251.8(7)$ \\
\hline $\mathrm{Zr}(1)-C(7)$ & $251.9(3)$ & $\mathrm{Zr}(1)-C(13)$ & $243.5(4)$ \\
\hline $\operatorname{Zr}(1)-C(8)$ & $248.7(3)$ & $\mathrm{Zr}(1)-C(14)$ & $250.0(7)$ \\
\hline $\mathrm{Zr}(1)-C(9)$ & $247.7(3)$ & $\mathrm{Zr}(1)-\mathrm{C}(15)$ & $259.2(6)$ \\
\hline $\mathrm{Zr}(1)-\mathrm{C}(10)$ & $252.4(3)$ & $\mathrm{Zr}(1)-\mathrm{C}(20)$ & $259.1(6)$ \\
\hline $\mathrm{Zr}(1)-\mathrm{CR}(1)$ & 223.5 & $\operatorname{Zr}(1)-C R(1)$ & 222.4 \\
\hline $\mathrm{Zr}(1)-\mathrm{CR}(2)$ & 221.5 & $\operatorname{Zr}(1)-C R(2)$ & 222.6 \\
\hline$N(1)-Z r(1)-O(1)$ & $68.4(1)$ & $N(1)-\operatorname{Zr}(1)-O(1)$ & $68.2(2)$ \\
\hline$N(1)-\operatorname{Zr}(1)-O(3)$ & $68.3(1)$ & $\mathrm{N}(1)-\mathrm{Zr}(1)-\mathrm{O}(2)$ & $68.0(2)$ \\
\hline $\mathrm{O}(1)-\mathrm{Zr}(1)-\mathrm{O}(3)$ & $136.6(1)$ & $O(1)-\operatorname{Zr}(1)-O(2)$ & $135.8(1)$ \\
\hline $\mathrm{CR}(1)-\operatorname{Zr}(1)-\mathrm{CR}(2)^{a}$ & 130.6 & $\mathrm{CR}(1)-\operatorname{Zr}(1)-\mathrm{CR}(2)^{\mathrm{a}}$ & 124.7 \\
\hline$P L(1)-P L(2)^{b}$ & 53.4 & PL(1)-PL(2) & 59.0 \\
\hline
\end{tabular}

${ }^{a}$ CR(1), CR(2): centroids of lower- and higher-numbered $\mathrm{C}_{5}$ rings, respectively. ${ }^{\mathrm{b}}$ PL(1), PL(2): mean planes of lower- and higher-numbered $\mathrm{C}_{5}$ rings, respectively. 

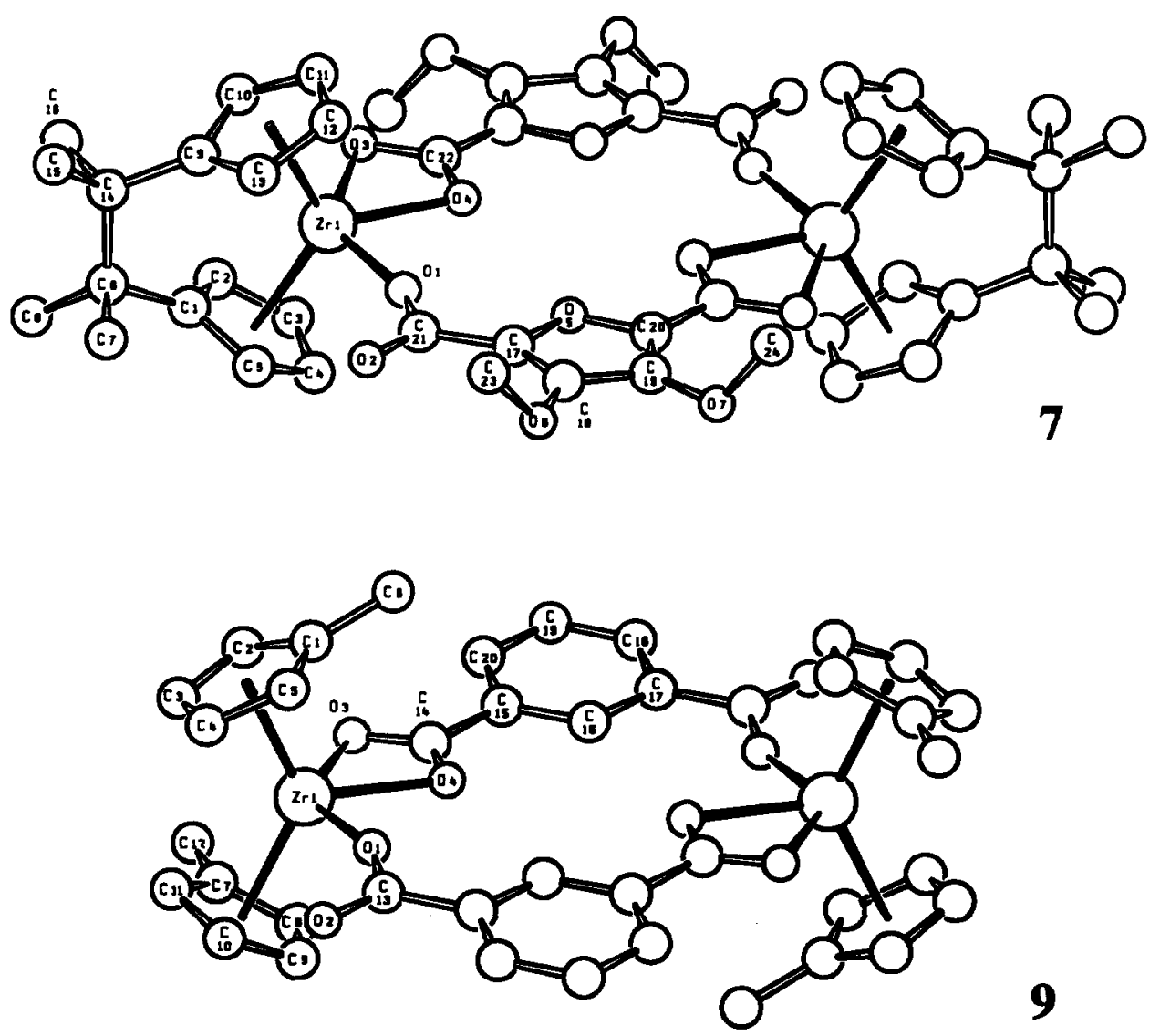

9

Fig. 2. Crystal structures of complexes 7 (top) and 9 (bottom).

TABLE 2. Selected distances (pm) and angles $\left(^{\circ}\right)$ for complexes 7 and 9

\begin{tabular}{|c|c|c|c|}
\hline & 7 & & 9 \\
\hline $\mathrm{Zr}(1)-\mathrm{O}(1)$ & $207.9(8)$ & $\mathrm{Zr}(1)-\mathrm{O}(1)$ & $207.6(5)$ \\
\hline $\mathrm{Zr}(1)-\mathrm{O}(3)$ & $233.5(5)$ & $\mathrm{Zr}(1)-O(3)$ & $230.6(5)$ \\
\hline $\mathrm{Zr}(1)-\mathrm{O}(4)$ & $222.5(5)$ & $\operatorname{Zr}(1)-O(4)$ & $226.2(5)$ \\
\hline $\operatorname{Zr}(1)-C(1)$ & 251.1(9) & $\operatorname{Zr}(1)-C(1)$ & $253.9(7)$ \\
\hline $\mathrm{Zr}(1)-\mathrm{C}(2)$ & $248.7(9)$ & $\mathrm{Zr}(1)-\mathrm{C}(2)$ & $252.2(6)$ \\
\hline $\mathrm{Zr}(1)-C(3)$ & $248.8(10)$ & $\mathrm{Zr}(1)-C(3)$ & $249.8(7)$ \\
\hline $\operatorname{Zr}(1)-C(4)$ & $250.5(15)$ & $\mathrm{Zr}(1)-C(4)$ & $246.8(9)$ \\
\hline $\operatorname{Zr}(1)-C(5)$ & $248.5(10)$ & $\mathrm{Zr}(1)-\mathrm{C}(5)$ & $251.7(8)$ \\
\hline $\operatorname{Zr}(1)-C(9)$ & $250.7(11)$ & $\operatorname{Zr}(1)-C(7)$ & $251.1(10)$ \\
\hline $\operatorname{Zr}(1)-C(10)$ & $247.0(15)$ & $\operatorname{Zr}(1)-C(8)$ & $250.7(11)$ \\
\hline $\mathrm{Zr}(1)-\mathrm{C}(11)$ & $247.0(17)$ & $\mathrm{Zr}(1)-C(9)$ & $252.2(12)$ \\
\hline $\mathrm{Zr}(1)-\mathrm{C}(12)$ & 248.4(13) & $\operatorname{Zr}(1)-C(10)$ & 251.1(13) \\
\hline $\mathrm{Zr}(1)-C(13)$ & $248.8(10)$ & $\mathrm{Zr}(1)-C(11)$ & $251.6(12)$ \\
\hline $\operatorname{Zr}(1)-C R(1)$ & 219.8 & $\mathrm{Zr}(1)-\mathrm{CR}(1)$ & 221.5 \\
\hline $\mathrm{Zr}(1)-\mathrm{CR}(2)$ & 218.6 & $\operatorname{Zr}(1)-C R(2)$ & 223.3 \\
\hline$O(1)-Z r(1)-O(3)$ & $133.4(2)$ & $O(1)-\operatorname{Zr}(1)-O(3)$ & $132.1(2)$ \\
\hline$O(1)-\operatorname{Zr}(1)-O(4)$ & $76.8(2)$ & $O(1)-\operatorname{Zr}(1)-O(4)$ & $75.6(2)$ \\
\hline$O(3)-Z r(1)-O(4)$ & $56.7(2)$ & $O(3)-Z r(1)-O(4)$ & $56.4(2)$ \\
\hline $\operatorname{CR}(1)-\operatorname{Zr}(1)-\operatorname{CR}(2)^{c}$ & 122.8 & $C R(1)-\operatorname{Zr}(1)-C R(2){ }^{c}$ & 130.5 \\
\hline PL(1)-PL(2) d & 56.8 & PL(1)-PL(2) ${ }^{d}$ & 51.2 \\
\hline
\end{tabular}

${ }^{c} \mathrm{CR}(1), \mathrm{CR}(2)$ : centroids of lower- and higher-numbered $\mathrm{C}_{5}$ rings, respectively. ${ }^{\mathrm{d}}$ PL(1), PL(2): mean planes of lower- and higher-numbered $\mathrm{C}_{5}$ rings, respectively. 

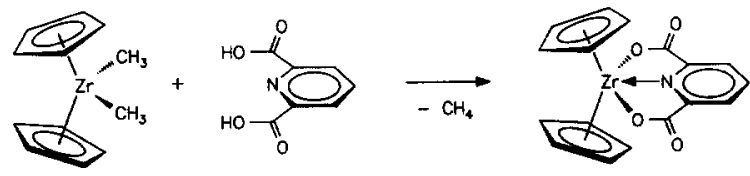

Method A
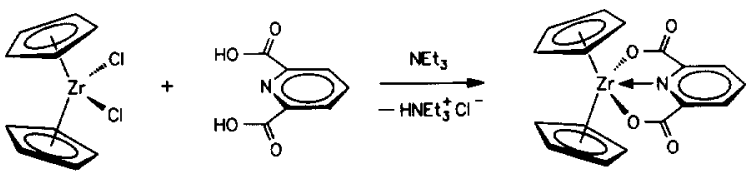

Method B

Scheme 1

Güthner [2]. (While their titanocene analogues tend to rearrange to dimers or polymers $[1,2]$, no such tendency is observed for these pentacoordinate zirconocene dipicolinate and oxidiacetate complexes.)

The $\mathrm{Zr}-\mathrm{O}$ and $\mathrm{Zr}-\mathrm{N}$ distances of 217-218 and 230-231 pm, respectively, observed in 2 and 4 , are comparable to values of $216-222 \mathrm{pm}$ for $\mathrm{Zr}-\mathrm{O}$ [2-8] and of $233-240 \mathrm{pm}$ for $\mathrm{Zr}-\mathrm{N}$ [3-5,9], reported for related pentacoordinate zirconocene complexes. No significant distortion of either the zirconocene or the dipicolinate moieties is apparent from these structures. In 2 , the mean plane of the dipicolinate ligand coincides with the zirconocene mid-plane, i.e. with the plane bisecting the centroid- $\mathrm{Zr}$-centroid angle within the error limits; in 4, it deviates from that plane by $c a$. $10^{\circ}$, probably due to crystal packing effects.

The crystal structure of the furandicarboxylate complex $\left[\left(\mathrm{CH}_{3}\right)_{4} \mathrm{C}_{2}\left(\mathrm{C}_{5} \mathrm{H}_{4}\right)_{2} \mathrm{Zr}\right.$ (DIFUR) ${ }_{2}$ (7) (Fig. 2, Table 2) confirms the dimeric nature of this species. The geometry of the furan dicarboxylate ligand appears to preclude its incorporation into a bicyclic, tridentate chelate structure analogous to that of the dipicolinate complexes. A model of such a monomeric complex indicates that $\mathrm{Zr}-\mathrm{O}$ distances to the lateral $\mathrm{O}$ atoms would have to be $245-250 \mathrm{pm}$, i.e. much too long, while the central $\mathrm{Zr}-\mathrm{O}$ bond, with $c a .200 \mathrm{pm}$, would be substantially too short compared with, for example, the structure of the stable, monomeric oxidiacetate (OXIDA) zirconocene complex $\left(\mathrm{C}_{5} \mathrm{H}_{5}\right)_{2} \mathrm{Zr}$ (OXIDA) [2].

The structure of 7 , which contains one bidentate and one monodentate carboxyl group in 7 is very similar, even in respect of the distribution of individual $\mathrm{Zr}-\mathrm{O}$ distances, to structures previously reported for other zirconocene dicarboxylate complexes $[10,11]$, but these consist of trimeric or polymeric complexes. (For related metallocene complexes with bidentate carboxy- late and alkane nitronate groups, $c f$. refs. 12-15.) The dimeric nature of 7 is probably connected with the particular angular arrangement of the carboxyl groups in the furandicarboxylate ligand. This hypothesis is supported by our observation that the similarly.kinked isophthalate ligand likewise forms a dimer $\left[\left(\mathrm{CH}_{3} \mathrm{C}_{5^{-}}\right.\right.$ $\left.\left.\mathrm{H}_{4}\right)_{2} \mathrm{Zr}(\mathrm{IPHTH})\right]_{2}$ (9). The overall structure of this complex, as determined by $\mathrm{X}$-ray diffraction (Fig. 2, Table 2), is very similar to that of 7 . The $\mathrm{Zr}_{2}$ (DIFUR) and $\mathrm{Zr}_{2}(\mathrm{IPHTH})_{2}$ cores of these two complexes are both practically planar.

The ${ }^{1} \mathrm{H}$ NMR spectra of complexes 1-9 (see Experimental section) are as expected from these structures. Noteworthy is the assignment of the $\alpha$ - and $\beta$-protons at the $C_{5}$ rings for the tetramethylethano-bridged complexes 3 and 7. Previously, we had observed that 16electron complexes of the type $\left(\mathrm{CH}_{3}\right)_{4} \mathrm{C}_{2}\left(\mathrm{C}_{5} \mathrm{H}_{4}\right)_{2} \mathrm{TiX}_{2}$ have their $\alpha-\mathrm{H}$ signals at higher fields than their $\beta-\mathrm{H}$ signals, while these signals occur in reversed order for 18-electron complexes such as $\left(\mathrm{CH}_{3}\right)_{4} \mathrm{C}_{2}\left(\mathrm{C}_{5} \mathrm{H}_{4}\right)_{2} \mathrm{Ti}$ $(\mathrm{CO})_{2},\left(\mathrm{CH}_{3}\right)_{4} \mathrm{C}_{2}\left(\mathrm{C}_{5} \mathrm{H}_{4}\right)_{2} \mathrm{Ti}\left(\mathrm{P}\left(\mathrm{CH}_{3}\right)_{3}\right)_{2}$ and $\left(\mathrm{CH}_{3}\right)_{4} \mathrm{C}_{2}$ $\left(\mathrm{C}_{5} \mathrm{H}_{4}\right)_{2} \mathrm{Cr}(\mathrm{CO})[16]$.

Nuclear Overhouser effect (NOE) studies on complexes 3 and 7 show that irradiation at the $\mathrm{CH}_{3}$ resonance of the tetramethylethano bridge selectively enhances the intensity of the low-field pseudotriplet by about $20 \%$. In both these complexes, the $\alpha$-H signals thus do indeed occur at lower field than the $\beta-\mathrm{H}$ signals (Table 3), as expected for 18-electron species of this type. (For $\left(\mathrm{CH}_{3}\right)_{4} \mathrm{C}_{2}\left(\mathrm{C}_{5} \mathrm{H}_{4}\right)_{2} \mathrm{ZrCl}_{2}$ in $\mathrm{CDCl}_{3}$, we find $\alpha-\mathrm{H}(6.16 \mathrm{pm})$ and $\beta-\mathrm{H}$ signals $(6.67 \mathrm{pm})$ in the same order as those for $\left(\mathrm{CH}_{3}\right)_{4} \mathrm{C}_{2}\left(\mathrm{C}_{5} \mathrm{H}_{4}\right)_{2} \mathrm{TiCl}_{2}$.) The tetramethylethano-bridged zirconocene oxidiacetate complex $\left(\mathrm{CH}_{3}\right)_{4} \mathrm{C}_{2}\left(\mathrm{C}_{5} \mathrm{H}_{4}\right)_{2} \mathrm{Zr}(\mathrm{OXIDA}), 10$, prepared from $\left(\mathrm{CH}_{3}\right)_{4} \mathrm{C}_{2}\left(\mathrm{C}_{5} \mathrm{H}_{4}\right)_{2} \mathrm{Zr}\left(\mathrm{CH}_{3}\right)_{2}$ and oxidiacetate acid, has its $\alpha-\mathrm{H}$ signal $(5.77 \mathrm{pm})$ likewise, albeit just barely, at lower field than its $\beta-\mathrm{H}$ signal $(5.73 \mathrm{pm})$ in $\mathrm{C}_{6} \mathrm{D}_{6}$ solution. (The corresponding values in $\mathrm{CDCl}_{3}$ are 6.17 and $6.14 \mathrm{ppm}$. The difference between $\alpha$ - and $\beta$ - $\mathrm{H}$ atom shifts in 16-electron species of the type $\left(\mathrm{CH}_{3}\right)_{4} \mathrm{C}_{2}\left(\mathrm{C}_{5} \mathrm{H}_{4}\right)_{2} \mathrm{MX}_{2}$ is substantially larger in $\mathrm{C}_{6} \mathrm{D}_{6}$ than in $\mathrm{CDCl}_{3}$, probably due to some residual binding of solvent molecules. For the 18-electron species considered here, very similar chemical shift differences are

TABLE 3. ${ }^{1} \mathrm{H}$ NMR chemical shifts (in ppm) for tetramethylethanobridged zirconocene complexes (250 $\mathrm{MHz}, \mathrm{CDCl}_{3}$ ); assignments derived from NOE experiments

\begin{tabular}{llll}
\hline & \multicolumn{3}{c}{$\mathrm{C}_{2}\left(\mathrm{CH}_{3}\right)_{4} \mathrm{C}_{5} \mathrm{H}_{4}(\alpha-\mathrm{H}) \mathrm{C}_{5} \mathrm{H}_{4}(\beta-\mathrm{H})$} \\
\hline$\left(\mathrm{CH}_{3}\right)_{4} \mathrm{C}_{2}\left(\mathrm{C}_{5} \mathrm{H}_{4}\right)_{2} \mathrm{ZrCl}_{2}$ & 1.47 & 6.16 & 6.68 \\
$\left(\mathrm{CH}_{3}\right)_{4} \mathrm{C}_{2}\left(\mathrm{C}_{5} \mathrm{H}_{4}\right)_{2} \mathrm{Zr}$ (DIPIC) & 1.57 & 6.21 & 5.92 \\
{$\left[\left(\mathrm{CH}_{3}\right)_{4} \mathrm{C}_{2}\left(\mathrm{C}_{5} \mathrm{H}_{4}\right)_{2} \mathrm{Zr} \text { (DIFUR) }\right]_{2} 1.53$} & 6.39 & 6.18 \\
$\left(\mathrm{CH}_{3}\right)_{4} \mathrm{C}_{2}\left(\mathrm{C}_{5} \mathrm{H}_{4}\right)_{2} \mathrm{Zr}$ (OXIDA) & 1.51 & 6.17 & 6.14 \\
\hline
\end{tabular}


observed in all these solvents.) Part of the high-field shift of the $\beta$-protons in 3 and 7 is thus probably due to the magnetic anisotropy of their aromatic mid-plane ligands. It appears, nevertheless, that the relative positions of $\alpha$ - and $\beta-H$ signals provide a useful diagnostic criterion for the presence of pentacoordinate, 18-electron metallocene complexes in solution.

\subsection{Reactivity studies}

Complexes 1-9 all proved to be stable towards water. No decomposition of these complexes was noticed when the side product triethylammonium chloride (method B) was removed by washing either the solid complexes or their $\mathrm{CHCl}_{3}$ solutions with water. All the complexes studied could be chromatographed on silica-gel thin-layer plates without noticeable decomposition. The dipicolinate complexes 3 and 4 were also purified by chromatography on a silica-gel column, from which they were recovered by elution with acetone and with diethyl ether/acetone $(5: 1)$, respectively, in $40-50 \%$ yield. The largely reversible adsorption on activated silica gel attests to the considerable inertness of these complexes. Normally, $\left(\mathrm{C}_{5} \mathrm{H}_{5}\right)_{2} \mathrm{ZrX}_{2}-$ type species are completely immobilized on silica gel, presumably due to an exchange of their $\mathrm{X}$ ligands by surface-hydroxyl groups. Only in rare instances have zirconocene complexes previously been found to be robust enough for elution from a silica-gel column [17].

Exposure of complexes 1-9 to concentrated $\mathrm{HCl}$ in a biphasic $\mathrm{CHCl}_{3}$ /aqueous reaction system leads to their reconversion into the corresponding dichlorides. This process is quite slow for the dipicolinate complexes 1-5, for which it requires 3-4 days. For complexes 6-9, the reaction is complete in less than $1 \mathrm{~h}$.

Finally, we have studied the reactions of complexes 1-9 towards metal alkyl species, as indicated in eqn. (1). No reaction with $\mathrm{CH}_{3} \mathrm{Li}$ in diethyl ether was apparent for the dipicolinate complexes 1-5, presumably due to their low solubility in this solvent.

With $\mathrm{CH}_{3} \mathrm{MgCl}$ in THF however, complexes 1-5 undergo an immediate reaction at room temperature with formation of an orange precipitate. The supernatant, colourless solution does not contain any dimethyl (or any other) zirconocene complex. Treatment of the orange precipitate with $\mathrm{CH}_{2} \mathrm{Cl}_{2} / 2 \mathrm{M}$ aqueous $\mathrm{HCl}$ causes immediate formation of the corresponding zirconocene dichloride. The organic reaction product is identified as 2,6-diacetylpyridine by ${ }^{1} \mathrm{H}$ NMR and mass spectra. Obviously, the methyl group of the Grignard reagent attacks these complexes at their carboxyl groups rather than at their $\mathrm{Zr}$ centre (Scheme 2). The insoluble orange intermediate is therefore likely to be the gem-diolate complex 11. The anionic oxygen in the latter is obviously much more susceptible to proto-

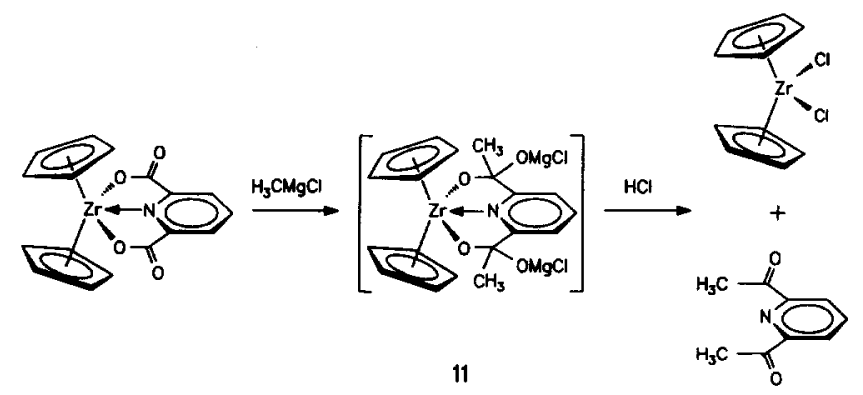

Scheme 2.

nation than the carboxylate groups in 1-5. (Attempts to transform this intermediate into a neutral, isolable complex by reaction with $\left(\mathrm{CH}_{3}\right)_{3} \mathrm{OBF}_{4}$ or with $\left(\mathrm{CH}_{3}\right)_{3} \mathrm{SiCl}$ afforded only diacetyl pyridine and zirconocene dihalide.)

In contrast, the dicarboxylate complexes 6-10 react with $\mathrm{CH}_{3} \mathrm{MgCl}$ in THF with rapid formation of the corresponding zirconocene dimethyl derivatives, as is normally observed for $\left(\mathrm{C}_{5} \mathrm{H}_{5}\right)_{2} \mathrm{ZrX}$-type zirconocenes (eqn. (1)). (In this case, ${ }^{1} \mathrm{H}$ NMR spectra indicate that the organic product is a mixture of the furandicarboxylate and the corresponding mono- and di-acetyl derivatives.) The $\mathrm{Zr}$ centres in these complexes are obviously readily accessible to nucleophilic attack, despite their pentacoordinate geometry. Probably, dissociation of one of the oxygen ligand atoms occurs readily enough in complexes 6-10 to allow for ligand exchange reactions to proceed without noticeable retardation. The more rigid structure of a dipicolinate complex, on the other hand, appears to reduce the rate of dissociation of its ligand atoms sufficiently to suppress any $S_{N} 1$-type substitution at the $\mathrm{Zr}$ centre. (The dianions of uncomplexed dipicolinate and dimethoxyfuran dicarboxylate appear to be about equally reactive toward $\mathrm{CH}_{3} \mathrm{MgCl}$, as indicated by a direct competition study. For reactions of carboxylates with Grignard reagents, $c f$. ref. 18.)

The inertness of zirconocene dipicolinate complexes toward ligand substitutions at the $\mathrm{Zr}$ centre, in combination with the reactivity of their carboxyl groups toward $\mathrm{CH}_{3} \mathrm{MgCl}$ and the facile removability of the ensuing diacetylpyridine fragment, suggests that dipicolinate ligands might be useful as protective groups in zirconocene chemistry.

\section{Experimental details}

All syntheses were performed under anhydrous conditions in a dry argon atmosphere, on a vacuum line or by Schlenk techniques; since some of the products appeared to be light-sensitive, light was excluded wherever possible. Solvents were purified by standard meth- 
ods and freshly distilled under argon before use. The starting materials $\left(\mathrm{C}_{5} \mathrm{H}_{5}\right)_{2} \mathrm{ZrCl}_{2}[19],\left(\mathrm{C}_{5} \mathrm{H}_{5}\right)_{2} \mathrm{Zr}\left(\mathrm{CH}_{3}\right)_{2}$ [20], $\left(\mathrm{CH}_{3} \mathrm{C}_{5} \mathrm{H}_{4}\right)_{2} \mathrm{ZrCl}_{2}$ [21], $\left(\mathrm{CH}_{3} \mathrm{C}_{5} \mathrm{H}_{4}\right)_{2} \mathrm{Zr}\left(\mathrm{CH}_{3}\right)_{2}$ [22], $\left(\mathrm{CH}_{3}\right)_{4} \mathrm{C}_{2}\left(\mathrm{C}_{5} \mathrm{H}_{4}\right)_{2} \mathrm{ZrCl}_{2}$ [23], rac- $\mathrm{C}_{2} \mathrm{H}_{4}(4,5,6,7$-tetrahydroindenyl ${ }_{2} \mathrm{ZrCl}_{2}$ [24], rac- $\mathrm{C}_{2} \mathrm{H}_{4}(4,5,6,7$-tetrahydroindenyl ${ }_{2} \mathrm{Zr}\left(\mathrm{CH}_{3}\right)_{2}$ [25], $\left(\mathrm{CH}_{3}\right)_{2} \mathrm{Si}$ (4-'butyl-2-meth$\left.\mathrm{ylC}_{5} \mathrm{H}_{2}\right)_{2} \mathrm{ZrCl}_{2}$ [26] and 3,4-dimethoxyfuran-2,5-dicarboxylic acid [27] were obtained by published procedures.

\section{1. $\left(\mathrm{CH}_{3}\right)_{4} \mathrm{C}_{2}\left(\mathrm{C}_{5} \mathrm{H}_{4}\right)_{2} \mathrm{Zr}\left(\mathrm{CH}_{3}\right)_{2}$}

Following the procedure described for $\left(\mathrm{C}_{5} \mathrm{H}_{5}\right)_{2} \mathrm{Zr}$ $\left(\mathrm{CH}_{3}\right)_{2}$ [20], $\left(\mathrm{CH}_{3}\right)_{4} \mathrm{C}_{2}\left(\mathrm{C}_{5} \mathrm{H}_{4}\right)_{2} \mathrm{ZrCl}_{2}(1.82 \mathrm{~g}, 5 \mathrm{mmol})$ was converted into $\left(\mathrm{CH}_{3}\right)_{4} \mathrm{C}_{2}\left(\mathrm{C}_{5} \mathrm{H}_{4}\right)_{2} \mathrm{Zr}\left(\mathrm{CH}_{3}\right)_{2}(0.79 \mathrm{~g}$, $2.4 \mathrm{mmol}, 48 \%$ of theory). ${ }^{1} \mathrm{H}$ NMR ( $\left.250 \mathrm{MHz}, \mathrm{C}_{6} \mathrm{D}_{6}\right)$ : $\delta 6.39(4 \mathrm{H}$, pt $2.44 \mathrm{~Hz}) ; 5.55(4 \mathrm{H}$, pt $2.44 \mathrm{~Hz}, 0.96$ $(12 \mathrm{H}, \mathrm{s}) ;-0.03(6 \mathrm{H}, \mathrm{s})(\mathrm{pt}=$ pseudotriplett $)$.

\subsection{Preparation of the dicarboxylate complexes 1-9}

The two methods (A and B) used for these preparations are described below for $\left(\mathrm{C}_{5} \mathrm{H}_{5}\right)_{2} \mathrm{Zr}$ (DIPIC) as an example. For the remaining complexes, only deviations from this standard procedure are reported.

\section{3. $\left(\mathrm{C}_{5} \mathrm{H}_{5}\right)_{2} \mathrm{Zr}(\mathrm{DIPIC})(1)$}

Method A: Solid dipicolinic acid $(1.67 \mathrm{~g}, 10 \mathrm{mmol})$ was added to a stirred solution of $\left(\mathrm{C}_{5} \mathrm{H}_{5}\right)_{2} \mathrm{Zr}\left(\mathrm{CH}_{3}\right)_{2}$ $(2.51 \mathrm{~g}, 10 \mathrm{mmol})$ in $50 \mathrm{ml}$ of THF at room temperature; this caused evolution of $\mathrm{CH}_{4}$. After overnight stirring, the precipitate was collected on a fritted disc, washed with $20 \mathrm{ml}$ of THF, and dried in vacuo. After recrystallization from methanol, 1 was isolated in $80 \%$ yield $(3.11 \mathrm{~g}, 8.05 \mathrm{mmol})$.

Method B: A mixture of $\left(\mathrm{C}_{5} \mathrm{H}_{5}\right)_{2} \mathrm{ZrCl}_{2}(2.92 \mathrm{~g}, 10$ $\mathrm{mmol})$ and dipicolinic acid $(1.67 \mathrm{~g}, 10 \mathrm{mmol})$ in $150 \mathrm{ml}$ of toluene was stirred and heated to $70^{\circ} \mathrm{C}$. A solution of triethylamine $(2.8 \mathrm{ml}, 20 \mathrm{mmol})$ in $50 \mathrm{ml}$ of toluene was slowly added to the suspension during $1 \mathrm{~h}$. After 5 $\mathrm{h}$ stirring at $70^{\circ} \mathrm{C}$ the mixture was allowed to cool to room temperature, stirred for another $12 \mathrm{~h}$, and then evaporated to dryness. The residue was taken up in 100 $\mathrm{ml}$ of water, the remaining solid filtered off, washed twice with $50 \mathrm{ml}$ of water, and recrystallized from methanol to yield $2.28 \mathrm{~g}$ of $1(5.9 \mathrm{mmol}, 60 \%$ of theory). ${ }^{1} \mathrm{H}$ NMR (250 MHz, $\mathrm{CDCl}_{3}$ ): $\delta$ 8.4-8.26 (3H, $\mathrm{m}) ; 6.25(10 \mathrm{H}, \mathrm{s})$. MS (FAB): $m / z \quad 386-390\left(\mathrm{MH}^{+}\right)$; 320-324 $\left(\mathrm{M}-\mathrm{C}_{5} \mathrm{H}_{6}{ }^{+}\right)$. DC (THF): $R_{\mathrm{f}}=0.67$.

\section{4. $\left(\mathrm{CH}_{3} \mathrm{C}_{5} \mathrm{H}_{4}\right)_{2} \mathrm{Zr}(\mathrm{DIPIC})(2)$}

Starting from $\left(\mathrm{CH}_{3} \mathrm{C}_{5} \mathrm{H}_{4}\right)_{2} \mathrm{Zr}\left(\mathrm{CH}_{3}\right)_{2}(2.34 \mathrm{~g}, 8.4$ mmol) and dipicolinic acid $(1.4 \mathrm{~g}, 8.4 \mathrm{mmol})$ in $60 \mathrm{ml}$ of THF, method A gave $2.72 \mathrm{~g}$ of raw product, which was purified by extraction with toluene for $24 \mathrm{~h}$ in a Soxhlet extractor. Evaporation of the extract gave $1.0 \mathrm{~g}$ of 2
(2.44 mmol, $30 \%$ of theory) as a colourless powder. Alternatively, $200 \mathrm{mg}$ of the raw product were dissolved in methanol and purified by chromatography on a silica gel column ( $2 \mathrm{~cm}$ diameter, $15 \mathrm{~cm}$ high) with acetone as eluent to yield $100 \mathrm{mg}(0.24 \mathrm{mmol}, 50 \%$ recovery) of 2 as a colourless solid. Method B, after crystallization from methanol, gave 2 in $82 \%$ theoretical yield. ${ }^{1} \mathrm{H}$ NMR $\left(250 \mathrm{MHz}, \mathrm{CDCl}_{3}\right): \delta 8.4-8.27(3 \mathrm{H}$, m); $6.25(4 \mathrm{H}$, pt $2.66 \mathrm{~Hz}) ; 5.8(4 \mathrm{H}$, pt $2.63 \mathrm{~Hz}) ; 1.85$ $(6 \mathrm{H}, \mathrm{s}) .{ }^{1} \mathrm{H}$ NMR $\left(250 \mathrm{MHz}, \mathrm{C}_{6} \mathrm{D}_{6}\right): \delta 7.8(2 \mathrm{H}, \mathrm{d} 7.63$ $\mathrm{Hz}) ; 6.97(1 \mathrm{H}, \mathrm{t} 7.63 \mathrm{~Hz}) ; 5.88(4 \mathrm{H}$, pt $2.47 \mathrm{~Hz}) ; 5.29$ (4H, pt $2.44 \mathrm{~Hz}$ ); $1.63(6 \mathrm{H}, \mathrm{s})$. MS (FAB): $m / z$ 414-418 $\left(\mathrm{MH}^{+}\right), 334-338\left(\mathrm{M}-\mathrm{CH}_{3} \mathrm{C}_{5} \mathrm{H}_{5}\right)$. DC (Aceton): $R_{\mathrm{f}}=$ 0.63 .

\section{5. $\left(\mathrm{CH}_{3}\right)_{4} \mathrm{C}_{2}\left(\mathrm{C}_{5} \mathrm{H}_{4}\right)_{2} \mathrm{Zr}$ (DIPIC) (3)}

From $\left(\mathrm{CH}_{3}\right)_{4} \mathrm{C}_{2}\left(\mathrm{C}_{5} \mathrm{H}_{4}\right)_{2} \mathrm{Zr}\left(\mathrm{CH}_{3}\right)_{2}(0.79 \mathrm{~g}, 2.4 \mathrm{mmol})$ and dipicolinic acid $(0.4 \mathrm{~g}, 2.4 \mathrm{mmol}), 0.84 \mathrm{~g}$ of colourless $\left(\mathrm{CH}_{3}\right)_{4} \mathrm{C}_{2}\left(\mathrm{C}_{5} \mathrm{H}_{4}\right)_{2} \mathrm{ZrDIPIC}(1.8 \mathrm{mmol}, 75 \%$ of theory) are obtained, after recrystallization from methanol, by method $\mathrm{A}$. In method B, the raw product obtained after evaporation of toluene was taken up in $\mathrm{CHCl}_{3}$ and water and extracted with $\mathrm{CHCl}_{3}$. The combined $\mathrm{CHCl}_{3}$ extracts were dried over anhydrous sodium sulfate and evaporated to dryness. After recrystallization from methanol, $1.44 \mathrm{~g}$ of $3(3.1 \mathrm{mmol}, 62 \%$ of theory) were obtained as colourless needles. ${ }^{1} \mathrm{H}$ NMR $\left(250 \mathrm{MHz}, \mathrm{C}_{6} \mathrm{D}_{6}\right): \delta 7.85(2 \mathrm{H}, \mathrm{d} 7.63 \mathrm{~Hz}) ; 7.0$ $(1 \mathrm{H}, \mathrm{t} 7.63 \mathrm{~Hz}) ; 5.82(4 \mathrm{H}$, pt $2.75 \mathrm{~Hz}) ; 5.44(4 \mathrm{H}$, pt 2.75 $\mathrm{Hz})$; $1.1(12 \mathrm{H}, \mathrm{s})$. MS (FAB): $m / z$ 468-472 $\left(\mathrm{MH}^{+}\right)$, 424-428 (M- $\left.\mathrm{CO}_{2}\right)$; 361-365 $\left(\mathrm{M}-\mathrm{C}_{8} \mathrm{H}_{11}\right)$. Elemental anal. Found: $\mathrm{C} 58.81, \mathrm{H} 5.02, \mathrm{~N} 2.8 . \mathrm{C}_{23} \mathrm{H}_{23} \mathrm{NO}_{4} \mathrm{Zr}$ calcd.: C 58.94, H 4.94, N 2.98\%. DC (acetone/ether, 2:1): $R_{\mathrm{f}}=0.60$.

3.6. rac- $\mathrm{C}_{2} \mathrm{H}_{4}(4,5,6,7 \text {-tetrahydroindenyl })_{2} \mathrm{Zr}(\mathrm{DIPIC})$ (4)

Starting from rac- $\mathrm{C}_{2} \mathrm{H}_{4}(4,5,6,7 \text {-tetrahydroindenyl })_{2}$ $\mathrm{Zr}\left(\mathrm{CH}_{3}\right)_{2}$ and dipicolinic acid, method $\mathrm{A}$, after recrystallization from methanol, yielded 4 in $63 \%$ theoretical yield. In method $\mathrm{B}$, the product was extracted from the solid product mixture with $\mathrm{CH}_{2} \mathrm{Cl}_{2}$ and recrystallized from methanol to give 4 in $38 \%$ theoretical yield. ${ }^{1} \mathrm{H}$ NMR $\left(250 \mathrm{MHz}, \mathrm{CDCl}_{3}\right): \delta 8.33-8.24(3 \mathrm{H}, \mathrm{m}) ; 5.72$ $(2 \mathrm{H}$, d $3.0 \mathrm{~Hz}) ; 5.63(2 \mathrm{H}$, d $3.0 \mathrm{~Hz}) ; 3.34-3.12(4 \mathrm{H}, \mathrm{m})$; 2.93-2.84 (2H, m); 2.7-2.58 (2H, m); 2.24-1.84 (6H, m); $1.55-1.46(6 \mathrm{H}, \mathrm{m}) .{ }^{1} \mathrm{H}$ NMR $\left(250 \mathrm{MHz}, \mathrm{C}_{6} \mathrm{D}_{6}\right): \delta$ $7.8(2 \mathrm{H}, \mathrm{d} 7.6 \mathrm{~Hz}) ; 6.92(1 \mathrm{H}, \mathrm{t} 7.6 \mathrm{~Hz}) ; 5.45(2 \mathrm{H}, \mathrm{d} 3.0$ $\mathrm{Hz}) ; 5.29$ (2H, d $3.0 \mathrm{~Hz}) ; 2.81-2.58(6 \mathrm{H}, \mathrm{m}) ; 2.31-2.14$ $(4 \mathrm{H}, \mathrm{m}) ; 2.04-1.89(4 \mathrm{H}, \mathrm{m}) ; 1.58-1.28(6 \mathrm{H}, \mathrm{m})$. MS (FAB): $m / z$ 520-524 $\left(\mathrm{MH}^{+}\right)$. Elemental anal. Found: C 62.08, $\mathrm{H}$ 5.12, N 2.25. $\mathrm{C}_{27} \mathrm{H}_{27} \mathrm{NO}_{4} \mathrm{Zr}$ calcd.: $\mathrm{C} 62.28$, H 5.22, N 2.67\%. DC (THF/pentane, $1: 1): \boldsymbol{R}_{\mathrm{f}}=0.41$. 
3.7. $\operatorname{rac}-\left(\mathrm{CH}_{3}\right)_{2} \mathrm{Si}\left(\text { 4- }^{t} \mathrm{Butyl}-2-\mathrm{MethylC} \mathrm{C}_{5} \mathrm{H}_{2}\right)_{2} \mathrm{Zr}(\mathrm{DIPIC})$ (5)

Starting from $\left(\mathrm{CH}_{3}\right)_{2} \mathrm{Si}\left(4-{ }^{t} \text { butyl-2-methylC }{ }_{5} \mathrm{H}_{2}\right)_{2} \mathrm{Zr}$ $\mathrm{Cl}_{2}(0.37 \mathrm{~g} 0.75 \mathrm{mmol})$ and dipicolinic acid $(0.126 \mathrm{~g}$, $0.75 \mathrm{mmol}$ ), method $\mathrm{B}$ gave $0.28 \mathrm{~g}$ of raw product, from which pure 5 was obtained by chromatography on a silica-gel column with diethyl ether/acetone $(5: 1)$ as eluent. ${ }^{1} \mathrm{H}$ NMR $\left(250 \mathrm{MHz}, \mathrm{CDCl}_{3}\right): \delta 8.33-8.19(3 \mathrm{H}$, $\mathrm{m}) ; 5.79(2 \mathrm{H}, \mathrm{d}) ; 5.46(2 \mathrm{H}, \mathrm{d}) ; 2.26(6 \mathrm{H}, \mathrm{s}) ; 0.88(6 \mathrm{H}, \mathrm{s}) ;$ $0.79(18 \mathrm{H}, \mathrm{s}, 18 \mathrm{H})$. MS (FAB): $m / z$ 582-592 $\left(\mathrm{MH}^{+}\right)$. DC (diethyl ether/acetone, $5: 1$ ): $R_{\mathrm{f}}=0.62$.

\section{8. $\left[\left(\mathrm{CH}_{3} \mathrm{C}_{5} \mathrm{H}_{4}\right)_{2} \mathrm{Zr}(\mathrm{DIFUR})\right]_{2}$ (6)}

In method $\mathrm{A}$, from 3,4-dimethoxyfuran-2,5-dicarboxylic acid $(2.06 \mathrm{~g}, 9.5 \mathrm{mmol})$ and $\left(\mathrm{CH}_{3} \mathrm{C}_{5} \mathrm{H}_{4}\right)_{2} \mathrm{Zr}\left(\mathrm{CH}_{3}\right)_{2}$ $(2.66 \mathrm{~g}, 9.5 \mathrm{mmol}) 6$ was obtained, after recrystallization in methanol, in $48 \%$ theoretical yield $(2.1 \mathrm{~g}, 2.27$ mmol dimer), as a colourless powder. Method B (ex- traction of the raw product with $\mathrm{CHCl}_{3}$ ) gave 6 in $57 \%$ theoretical yield. ${ }^{1} \mathrm{H}$ NMR $\left(250 \mathrm{MHz}, \mathrm{CDCl}_{3}\right): \delta 6.26$ $(8 \mathrm{H}$, pt $2.7 \mathrm{~Hz}) ; 6.02(8 \mathrm{H}$, pt $2.7 \mathrm{~Hz}) ; 4.16(12 \mathrm{H}, \mathrm{s}) ; 2.08$ (12H, s). MS (FAB): $m / z$ 926-934 $\left(\mathrm{MH}^{+}\right) ; 462-468$ $\left((\mathrm{M} / 2) \mathrm{H}^{+}\right) ; 418-422\left((\mathrm{M} / 2)-\mathrm{CO}_{2}\right)$. DC (methanol): $R_{\mathrm{f}}=0.64$.

\section{9. $\left[\left(\mathrm{CH}_{3}\right)_{4} \mathrm{C}_{2}\left(\mathrm{C}_{5} \mathrm{H}_{4}\right)_{2} \mathrm{Zr}(\mathrm{DIFUR})\right]_{2}$ (7)}

In method $\mathrm{A}$, from 3,4-dimethoxyfuran-2,5-dicarboxylic acid and $\left(\mathrm{CH}_{3}\right)_{4} \mathrm{C}_{2}\left(\mathrm{C}_{5} \mathrm{H}_{4}\right)_{2} \mathrm{Zr}\left(\mathrm{CH}_{3}\right)_{2}, 7$ was obtained, after recrystallization from methanol, in $62 \%$ theoretical yield. Method B gave 7 in $57 \%$ of theory. ${ }^{1} \mathrm{H}$ NMR (250 MHz, $\left.\mathrm{CDCl}_{3}\right): \delta 6.39(8 \mathrm{H}$, pt $2.6 \mathrm{~Hz})$; $6.18(8 \mathrm{H}$, pt $2.6 \mathrm{~Hz}) ; 4.16(12 \mathrm{H}, \mathrm{s}) ; 1.53(24 \mathrm{H}, \mathrm{s})$. MS (FAB): $m / z$ 1032-1040 $\left(\mathrm{MH}^{+}\right) ; 834-842(\mathrm{M}-$ $\left.\mathrm{C}_{8} \mathrm{H}_{6} \mathrm{O}_{6}\right) ; 517-521\left((\mathrm{M} / 2) \mathrm{H}^{+}\right)$; 473-477 ((M/2)$\left.\mathrm{CO}_{2}\right) ; 318-322\left((\mathrm{M} / 2)-\mathrm{C}_{8} \mathrm{H}_{7} \mathrm{O}_{6}\right)$. DC (methanol): $R_{\mathrm{f}}=0.68$.

TABLE 4. Crystallographic and experimental data for complexes $\mathrm{C}_{19} \mathrm{H}_{17} \mathrm{NO}_{4} \mathrm{Zr}(2), \mathrm{C}_{27} \mathrm{H}_{27} \mathrm{NO}_{4} \mathrm{Zr}(4), \mathrm{C}_{25} \mathrm{H}_{27} \mathrm{Cl}_{3} \mathrm{O}_{7} \mathrm{Zr}_{2}(7)$ and $\mathrm{C}_{40} \mathrm{H}_{36} \mathrm{O}_{8} \mathrm{Zr} 2$ (9)

\begin{tabular}{|c|c|c|c|c|}
\hline & 2 & 4 & 7 & 9 \\
\hline $\begin{array}{l}\text { Formula } \\
\text { FW }\end{array}$ & $\begin{array}{l}\mathrm{C}_{19} \mathrm{H}_{17} \mathrm{NO}_{4} \mathrm{Zr} \\
414.6\end{array}$ & $\begin{array}{l}\mathrm{C}_{27} \mathrm{H}_{27} \mathrm{NO}_{4} \mathrm{Zr} \\
520.7\end{array}$ & $\begin{array}{l}\mathrm{C}_{48} \mathrm{H}_{52} \mathrm{O}_{14} \mathrm{Zr}_{2} \cdot 2 \mathrm{CHCl}_{3} \\
1274\end{array}$ & $\begin{array}{l}\mathrm{C}_{40} \mathrm{H}_{36} \mathrm{O}_{8} \mathrm{Zr}_{2} \\
827.1\end{array}$ \\
\hline Crystal colour, form & Colourless cube & Pale yellow & Colourless plate & Colourless cube \\
\hline Crystal system & Monoclinic & Monoclinic & Monoclinic & Monoclinic \\
\hline $\begin{array}{l}\text { Space group } \\
a(\mathrm{pm})\end{array}$ & $\begin{array}{l}P 2_{1} / n \\
775.8(3)\end{array}$ & $\begin{array}{l}P 2_{1} \\
908.7(4)\end{array}$ & $\begin{array}{l}P 2_{1} / c \\
1624.6(3)\end{array}$ & $\begin{array}{l}P 2_{1} / n \\
1216.6(4)\end{array}$ \\
\hline$b(\mathrm{pm})$ & $2570.6(13)$ & $829.8(3)$ & $1196.8(2)$ & $892.7(3)$ \\
\hline$c(\mathrm{pm})$ & $854.6(4)$ & $1497.5(6)$ & $1484.4(3)$ & $1707.7(6)$ \\
\hline \multicolumn{5}{|l|}{$\alpha\left(^{\circ}\right)$} \\
\hline$\beta\left(^{\circ}\right)$ & $93.87(3)$ & $100.23(3)$ & $112.950(10)$ & $110.79(2)$ \\
\hline \multicolumn{5}{|l|}{$\gamma\left(0^{\circ}\right)$} \\
\hline$V\left(10^{6} \mathrm{pm}^{3}\right)$ & $1700.5(13)$ & $1111.3(7)$ & $2657.6(9)$ & 1733.9(9) \\
\hline$d_{\text {calcd }}\left(\mathrm{g} \mathrm{cm}^{-3}\right)$ & 1.619 & 1.556 & 1.592 & 1.584 \\
\hline$z$ & 4 & 2 & 2 & 2 \\
\hline $\begin{array}{l}\text { Crystal dimensions } \\
\left(\mathrm{mm}^{3}\right)\end{array}$ & $0.5 \times 0.5 \times 0.5$ & $0.2 \times 0.2 \times 0.2$ & $0.3 \times 0.3 \times 0.1$ & $0.3 \times 0.3 \times 0.3$ \\
\hline \multicolumn{5}{|l|}{ Absolute coefficient } \\
\hline$(\mu)\left(\mathrm{cm}^{-1}\right)$ & 6.57 & 5.19 & 7.51 & 6.43 \\
\hline$T[\mathrm{~K}]$ & 296 & 297 & 296 & 296 \\
\hline Weighting scheme & $w^{-1}=\sigma^{2}(F)=0.0002 F^{2}$ & $w^{-1}=\sigma^{2}(F)=0.0004 F^{2}$ & $w^{-1}=\sigma^{2}(F)+0.0000 F^{2}$ & $w^{-1}=\sigma^{2}(F)+0.0004 F^{2}$ \\
\hline Scan mode & Wyckoff & Wyckoff & Wyckoff & Wyckoff \\
\hline Scan range $\left(^{\circ}\right)$ & 0.7 & 0.7 & 0.6 & 0.7 \\
\hline $2 \theta$ range $\left(^{\circ}\right)$ & 4.0 to 52.0 & 4.0 to 54.0 & 4.0 to 54.0 & 4.0 to 54.0 \\
\hline Scan speed $\left({ }^{\circ} \min ^{-1}\right)$ & $2.3-29.3$ & $2.0-29.3$ & $2.3-29.3$ & $2.0-29.3$ \\
\hline No. of data collected & 7391 & 2763 & 6315 & 4233 \\
\hline No. of independent data & 3356 & 2598 & 5798 & 3793 \\
\hline No. of unique data & 2969 & 2333 & 2357 & 2293 \\
\hline Observed criterion & $F>4.0 \sigma(F)$ & $F>3.0 \sigma(F)$ & $F>4.0 \sigma(F)$ & $F>4.0 \sigma(F)$ \\
\hline No. of parameters & 226 & 298 & 325 & 226 \\
\hline$R_{\mathrm{F}}^{\mathrm{b}}$ & 0.027 & 0.035 & 0.067 & 0.059 \\
\hline$R_{\mathrm{wF}}^{\mathrm{c}}$ & 0.040 & 0.037 & 0.045 & 0.062 \\
\hline \multicolumn{5}{|l|}{ Residual density } \\
\hline$\left(10^{-6} \mathrm{epm}^{-3}\right)$ & 0.36 & 0.33 & 0.56 & 0.85 \\
\hline
\end{tabular}

Conditions: Syntex/Siemens-P3 four circle diffractometer, Mo $\mathrm{K} \alpha$ radiation, $71.073 \mathrm{pm}$, graphite monochromator.

${ }^{\mathrm{b}} R_{\mathrm{F}}=\Sigma\left\|F_{\mathrm{o}}|-| F_{\mathrm{c}}\right\| / \Sigma\left|F_{\mathrm{c}} \delta\right| .{ }^{\mathrm{c}} R_{\mathrm{wF}}=\left[\Sigma w\left(\left|F_{\mathrm{o}}\right|-\left|F_{\mathrm{c}}\right|\right)^{2} / \Sigma F_{\mathrm{o}}^{2}\right]^{1 / 2}$ 
3.10. $\mathrm{rac}-\mathrm{CC}_{2} \mathrm{H}_{4}(4,5,6,7-\text { tetrahydroindenyl })_{2} \mathrm{Zr}(\mathrm{DI}$ FUR $]_{2}(8)$

Starting from rac- $\mathrm{C}_{2} \mathrm{H}_{4}(4,5,6,7 \text {-tetrahydroindenyl) })_{2}$ $\mathrm{ZrCl}_{2}(0.55 \mathrm{~g}, 1.3 \mathrm{mmol})$ and 3,4-dimethoxyfuran-2,5dicarboxylic acid $(0.28 \mathrm{~g}, 1.3 \mathrm{mmol}), 0.29 \mathrm{~g}$ of 8 were obtained by method B (40\% theoretical yield). ${ }^{1} \mathrm{H}$ NMR $\left(250 \mathrm{MHz}, \mathrm{CDCl}_{3}\right): \delta 5.93(4 \mathrm{H}, \mathrm{d} 2.9 \mathrm{~Hz}) ; 5.79$ $(4 \mathrm{H}$, d $2.9 \mathrm{~Hz}) ; 4.14(12 \mathrm{H}, \mathrm{s}) ; 3.16-3.09(4 \mathrm{H}, \mathrm{m})$; 2.91-2.83 (4H, m); 2.63-2.56 (8H, m); 2.35-2.32 (12H, $\mathrm{m})$; $1.91-1.83(4 \mathrm{H}, \mathrm{m}) ; 1.72-1.63(8 \mathrm{H}, \mathrm{m})$. MS (FAB): $m / z$ 1138-1146 $\left(\mathrm{MH}^{+}\right) ; 569-573\left((\mathrm{M} / 2) \mathrm{H}^{+}\right) ; 525-529$ $\left((\mathrm{M} / 2)-\mathrm{CO}_{2}\right) ; 371-375\left((\mathrm{M} / 2)-\mathrm{C}_{8} \mathrm{H}_{6} \mathrm{O}_{6}\right)$.

\subsection{1. $\left[\left(\mathrm{CH}_{3} \mathrm{C}_{5} \mathrm{H}_{4}\right)_{2} \mathrm{Zr}(\text { IPHTH })\right]_{2}$ (9)}

From isophthalic acid $(1.56 \mathrm{~g}, 9.4 \mathrm{mmol})$ and $\left(\mathrm{CH}_{3} \mathrm{C}_{5} \mathrm{H}_{4}\right)_{2} \mathrm{Zr}\left(\mathrm{CH}_{3}\right)_{2}(2.62 \mathrm{~g}, 9.4 \mathrm{mmol})$ complex 9 was obtained by method $\mathrm{A}$, after diffusion-induced crystallization from pentene $/ \mathrm{CH}_{2} \mathrm{Cl}_{2}$, in a theoretical yield of $28 \%(1.07 \mathrm{~g}, 1.3 \mathrm{mmol}) .{ }^{1} \mathrm{H}$ NMR $(250 \mathrm{MHz}$, $\left.\mathrm{CDCl}_{3}\right): \delta 9.3(2 \mathrm{H}, \mathrm{t} 1.5 \mathrm{~Hz}) ; 8.32-8.28(4 \mathrm{H}$, dd 1.5 $\mathrm{Hz}) ; 7.58(2 \mathrm{H}, \mathrm{t} 7.6 \mathrm{~Hz}) ; 6.32(8 \mathrm{H}$, pt $2.5 \mathrm{~Hz}) ; 6.04(8 \mathrm{H}$, pt $2.5 \mathrm{~Hz}) ; 2.02(12 \mathrm{H}, \mathrm{s})$. MS (FAB): $\mathrm{m} / \mathrm{z} 825-833$ $\left(\mathrm{MH}^{+}\right)$; 746-754 (M- $\left.\mathrm{C}_{6} \mathrm{H}_{7}\right)$; 413-417 ((M/2)H $\left.\mathrm{H}^{+}\right)$; 369-373 $\left((\mathrm{M} / 2)-\mathrm{CO}_{2}\right)$. Elemental anal. Found: $\mathrm{C}$ 57.88, H 4.44. $\mathrm{C}_{40} \mathrm{H}_{36} \mathrm{O}_{8} \mathrm{Zr}_{2}$ calcd.: C 58.08, $\mathrm{H} 4.38 \%$.

TABLE 5. Atomic coordinates $\left(\times 10^{4}\right)$ and equivalent isotropic displacement coefficients $\left(\mathrm{pm}^{2} \times 10^{-1}\right)$ for complex 2

\begin{tabular}{lrrrr}
\hline & \multicolumn{1}{l}{$y$} & \multicolumn{1}{l}{$\boldsymbol{z}$} & \multicolumn{1}{c}{$U_{\mathrm{eq}}{ }^{\mathrm{a}}$} \\
\hline $\mathrm{Zr}(1)$ & $583.3(3)$ & $1200.2(1)$ & $608.0(2)$ & $30(1)$ \\
$\mathrm{N}(1)$ & $2501(2)$ & $1302(1)$ & $2773(2)$ & $35(1)$ \\
$\mathrm{O}(1)$ & $1655(2)$ & $456(1)$ & $1425(2)$ & $41(1)$ \\
$\mathrm{O}(2)$ & $3376(3)$ & $-34(1)$ & $3021(2)$ & $62(1)$ \\
$\mathrm{O}(3)$ & $821(2)$ & $2013(1)$ & $1322(2)$ & $43(1)$ \\
$\mathrm{O}(4)$ & $1974(3)$ & $2653(1)$ & $2808(3)$ & $71(1)$ \\
$\mathrm{C}(1)$ & $1875(5)$ & $1711(1)$ & $-1659(3)$ & $61(1)$ \\
$\mathrm{C}(2)$ & $3103(4)$ & $1346(2)$ & $-1094(3)$ & $60(1)$ \\
$\mathrm{C}(3)$ & $2465(5)$ & $854(1)$ & $-1442(3)$ & $66(1)$ \\
$\mathrm{C}(4)$ & $860(5)$ & $900(2)$ & $-2100(3)$ & $72(1)$ \\
$\mathrm{C}(5)$ & $451(4)$ & $1432(2)$ & $-2247(3)$ & $72(1)$ \\
$\mathrm{C}(6)$ & $-1692(3)$ & $827(1)$ & $2345(3)$ & $46(1)$ \\
$\mathrm{C}(7)$ & $-2005(3)$ & $620(1)$ & $833(3)$ & $50(1)$ \\
$\mathrm{C}(8)$ & $-2508(3)$ & $1027(1)$ & $-179(3)$ & $55(1)$ \\
$\mathrm{C}(9)$ & $-2455(3)$ & $1492(1)$ & $671(4)$ & $55(1)$ \\
$\mathrm{C}(10)$ & $-1957(4)$ & $1363(1)$ & $2238(3)$ & $51(1)$ \\
$\mathrm{C}(11)$ & $2112(7)$ & $2282(2)$ & $-1702(6)$ & $141(3)$ \\
$\mathrm{C}(12)$ & $-1260(5)$ & $522(2)$ & $3810(3)$ & $78(1)$ \\
$\mathrm{C}(13)$ & $3276(3)$ & $881(1)$ & $3432(2)$ & $38(1)$ \\
$\mathrm{C}(14)$ & $4407(3)$ & $928(1)$ & $4755(3)$ & $46(1)$ \\
$\mathrm{C}(15)$ & $4730(3)$ & $1416(1)$ & $5366(3)$ & $50(1)$ \\
$\mathrm{C}(16)$ & $3939(3)$ & $1855(1)$ & $4674(3)$ & $47(1)$ \\
$\mathrm{C}(17)$ & $2804(3)$ & $1776(1)$ & $3350(3)$ & $40(1)$ \\
$\mathrm{C}(18)$ & $2772(3)$ & $383(1)$ & $2593(3)$ & $40(1)$ \\
$\mathrm{C}(19)$ & $1816(3)$ & $2193(1)$ & $2459(3)$ & $44(1)$ \\
\hline
\end{tabular}

a Equivalent isotropic $U$ defined as one-third of the trace of the orthogonalized $U_{i j}$ tensor.
TABLE 6. Atomic coordinates $\left(\times 10^{4}\right)$ and equivalent isotropic displacement coefficients $\left(\mathrm{pm}^{2} \times 10^{-1}\right)$ for complex 4

\begin{tabular}{|c|c|c|c|c|}
\hline & $x$ & $y$ & $z$ & $U_{\text {eq }}{ }^{a}$ \\
\hline $\mathrm{Zr}(1)$ & $8818.1(4)$ & 0 & $7565.7(2)$ & $27(1)$ \\
\hline$C(1)$ & $8012(7)$ & $-2722(8)$ & $7109(4)$ & $42(2)$ \\
\hline$C(2)$ & $6681(6)$ & $-1883(8)$ & 7081(4) & $38(2)$ \\
\hline$C(3)$ & $6511(6)$ & $-1492(8)$ & $7964(3)$ & $36(2)$ \\
\hline$C(4)$ & $5220(6)$ & $-690(9)$ & $8314(4)$ & $52(2)$ \\
\hline$C(5)$ & $5245(8)$ & $-1119(16)$ & $9285(5)$ & $97(4)$ \\
\hline$C(6)$ & $6602(8)$ & $-1243(15)$ & $9874(4)$ & 92(4) \\
\hline$C(7)$ & $7921(7)$ & $-2071(9)$ & $9582(4)$ & $48(2)$ \\
\hline$C(8)$ & $7766(7)$ & $-2108(8)$ & $8563(4)$ & $35(2)$ \\
\hline$C(9)$ & $8707(6)$ & $-2895(7)$ & $8045(3)$ & $38(2)$ \\
\hline$C(10)$ & $10189(6)$ & $-3699(8)$ & $8383(4)$ & $48(2)$ \\
\hline$C(11)$ & $11375(7)$ & $-3137(8)$ & $7844(5)$ & $52(2)$ \\
\hline$C(12)$ & $11340(8)$ & $-1341(10)$ & $7754(5)$ & $38(2)$ \\
\hline$C(13)$ & $11332(5)$ & $-214(10)$ & $8448(3)$ & $38(2)$ \\
\hline$C(14)$ & $11283(7)$ & $1355(10)$ & $8069(5)$ & $38(2)$ \\
\hline$C(15)$ & $11243(6)$ & $1190(8)$ & $7144(5)$ & $33(2)$ \\
\hline$C(16)$ & $11284(7)$ & $2493(8)$ & $6437(4)$ & $47(2)$ \\
\hline $\mathrm{C}(17)$ & $11990(8)$ & $1764(10)$ & $5649(4)$ & $59(2)$ \\
\hline$C(18)$ & $11206(7)$ & $261(11)$ & $5284(4)$ & $60(3)$ \\
\hline$C(19)$ & $11357(7)$ & $-1080(9)$ & $5999(4)$ & $48(2)$ \\
\hline$C(20)$ & $11256(6)$ & $-453(7)$ & $6928(4)$ & $33(2)$ \\
\hline$O(1)$ & $8555(4)$ & $1312(6)$ & $8785(2)$ & $39(1)$ \\
\hline$C(21)$ & $7749(7)$ & $2584(8)$ & $8824(4)$ & $38(2)$ \\
\hline $\mathrm{O}(21)$ & $7643(5)$ & $3341(7)$ & $9512(3)$ & $62(2)$ \\
\hline$C(22)$ & $6898(5)$ & 3091(7) & $7918(3)$ & $36(2)$ \\
\hline$C(23)$ & $5826(6)$ & $4286(8)$ & $7763(4)$ & $45(2)$ \\
\hline$C(24)$ & $5139(7)$ & $4595(7)$ & $6867(5)$ & $53(2)$ \\
\hline$C(25)$ & $5540(6)$ & $3682(8)$ & $6178(4)$ & $45(2)$ \\
\hline$C(26)$ & $6596(6)$ & $2496(7)$ & $6377(3)$ & $36(2)$ \\
\hline$C(27)$ & $7145(5)$ & $1359(7)$ & $5720(3)$ & $35(2)$ \\
\hline$O(27)$ & 6598(5) & $1379(6)$ & $4915(2)$ & $55(1)$ \\
\hline$O(2)$ & $8168(4)$ & $382(5)$ & $6106(2)$ & $37(1)$ \\
\hline$N(1)$ & $7263(5)$ & $2210(7)$ & $7237(3)$ & $31(1)$ \\
\hline
\end{tabular}

aquivalent isotropic $U$ defined as one-third of the trace of the orthogonalized $U_{i j}$ tensor.

\subsection{2. $\left(\mathrm{CH}_{3}\right)_{4} \mathrm{C}_{2}\left(\mathrm{C}_{5} \mathrm{H}_{4}\right)_{2} \mathrm{Zr}(\mathrm{OXIDA})$ (10)}

From $\left(\mathrm{CH}_{3}\right)_{4} \mathrm{C}_{2}\left(\mathrm{C}_{5} \mathrm{H}_{4}\right)_{2} \mathrm{Zr}\left(\mathrm{CH}_{3}\right)_{2}(1.36 \mathrm{~g}, 4.1 \mathrm{mmol})$ and oxidiacetic acid $(0.55 \mathrm{~g} 4.1 \mathrm{mmol}), 1.35 \mathrm{~g}$ of complex $10(76 \%$ theoretical yield) were obtained by method A. ${ }^{1} \mathrm{H}$ NMR $\left(250 \mathrm{MHz}, \mathrm{CDCl}_{3}\right): \delta 6.17(4 \mathrm{H}, \mathrm{pt}$ $2.4 \mathrm{~Hz}) ; 6.14(4 \mathrm{H}$, pt $2.4 \mathrm{~Hz}) ; 4.21(4 \mathrm{H}, \mathrm{s}) ; 1.51(12 \mathrm{H}, \mathrm{s})$. MS(FAB): $m / z$ 435-439 $\left(\mathrm{MH}^{+}\right)$.

\subsection{Reaction of $\left(\mathrm{CH}_{3} \mathrm{C}_{5} \mathrm{H}_{4}\right)_{2} \mathrm{Zr}(\mathrm{DIPIC})$ with $\left(\mathrm{CH}_{3}\right)$ - $\mathrm{MgCl}$}

To a stirred suspension of $\left(\mathrm{CH}_{3} \mathrm{C}_{5} \mathrm{H}_{4}\right)_{2} \mathrm{Zr}$ (DIPIC) $(0.98 \mathrm{~g}, 2.4 \mathrm{mmol})$ in $90 \mathrm{ml}$ of THF, $4 \mathrm{ml}$ of a $2.5 \mathrm{M}$ solution of $\left(\mathrm{CH}_{3}\right) \mathrm{MgCl}$ in THF $(9.7 \mathrm{mmol})$ were slowly added; this caused a change in colour from colourless to orange. After overnight stirring, the solution was evaporated to dryness and the residue extracted with pentane. The extract contained no $\left(\mathrm{CH}_{3} \mathrm{C}_{5} \mathrm{H}_{4}\right)_{2} \mathrm{Zr}$ $\left(\mathrm{CH}_{3}\right)_{2}\left({ }^{1} \mathrm{H}\right.$ NMR in $\left.\mathrm{C}_{6} \mathrm{D}_{6}\right)$. The residual solid was shaken with a mixture of $50 \mathrm{ml}$ of $\mathrm{CH}_{2} \mathrm{Cl}_{2}$ and $10 \mathrm{ml}$ of 
$2 \mathrm{M}$ aqueous $\mathrm{HCl}$. The $\mathrm{CH}_{2} \mathrm{Cl}_{2}$ extract was dried over anhydrous $\mathrm{Na}_{2} \mathrm{SO}_{4}$ and evaporated in vacuo. The residue was found by ${ }^{1} \mathrm{H}$ NMR $\left(250 \mathrm{MHz}, \mathrm{CDCl}_{3}\right)$ to consist of a $1: 1$ mixture of $\left(\mathrm{CH}_{3} \mathrm{C}_{5} \mathrm{H}_{4}\right)_{2} \mathrm{ZrCl}_{2}(\delta 6.28$ $(4 \mathrm{H}, \mathrm{pt} 2.6 \mathrm{~Hz}) ; 6.19(4 \mathrm{H}, \mathrm{pt} 2.6 \mathrm{~Hz}) ; 2.27(6 \mathrm{H}, \mathrm{s}))$ and 2,6-diacetyl-pyridine $(\delta 8.21(2 \mathrm{H}, \mathrm{d} 7.7 \mathrm{~Hz}) ; 7.98(1 \mathrm{H}, \mathrm{t}$ $7.7 \mathrm{~Hz}) ; 2.79(6 \mathrm{H}, \mathrm{s})$. MS(EI) $m / z 163\left(\mathrm{M}^{+}\right)$.

\subsection{Crystal structure determinations}

Suitable crystals of complexes 2 and 7 were obtained by slow evaporation of methanol and chloroform solutions, respectively, crystals of 4 and 9 by diffusion-induced crystallization from methanol/ether and pentane $/ \mathrm{CH}_{2} \mathrm{Cl}_{2}$, respectively. Space group determination, diffraction data collection and solution and refinement of the structures were conducted as summa-

TABLE 7. Atomic coordinates $\left(\times 10^{4}\right)$ and equivalent isotropic displacement coefficients $\left(\mathrm{pm}^{2} \times 10^{-1}\right)$ for complex 7

\begin{tabular}{|c|c|c|c|c|}
\hline & $x$ & $y$ & $z$ & $U_{\mathrm{eq}}{ }^{\mathrm{a}}$ \\
\hline $\mathrm{Zr}(1)$ & $2249(1)$ & $1380(1)$ & $287(1)$ & $44(1)$ \\
\hline$O(1)$ & $2053(4)$ & $688(5)$ & $1473(5)$ & $59(3)$ \\
\hline$O(2)$ & 2992(4) & $472(6)$ & $3012(5)$ & $71(3)$ \\
\hline$O(3)$ & $1336(3)$ & 1575(5) & $-1369(4)$ & $61(3)$ \\
\hline$O(4)$ & $862(3)$ & $715(6)$ & $-379(5)$ & $62(3)$ \\
\hline$O(5)$ & $740(3)$ & $-310(5)$ & $1721(4)$ & $45(3)$ \\
\hline$O(6)$ & $2069(4)$ & $-958(5)$ & 4197(4) & $55(3)$ \\
\hline$O(7)$ & 261(4) & $-1776(5)$ & $3531(5)$ & $58(3)$ \\
\hline $\mathrm{Cl}(1 *)$ & $2623(2)$ & $-1052(4)$ & $6839(3)$ & $144(2)$ \\
\hline $\mathrm{Cl}(2 *)$ & $1264(2)$ & $-2631(3)$ & $5887(2)$ & $123(2)$ \\
\hline $\mathrm{Cl}(3 *)$ & $811(2)$ & $-528(3)$ & 6442(3) & $124(2)$ \\
\hline$C(1 *)$ & $1537(6)$ & $-1207(8)$ & $6053(7)$ & $67(5)$ \\
\hline$C(1)$ & $3249(6)$ & $3050(8)$ & $890(8)$ & $55(5)$ \\
\hline$C(2)$ & $2586(7)$ & $3341(7)$ & $-3(8)$ & $56(5)$ \\
\hline$C(3)$ & 1751(8) & $3363(9)$ & $56(11)$ & $87(7)$ \\
\hline$C(4)$ & $1896(9)$ & $3118(10)$ & $1006(12)$ & $95(9)$ \\
\hline C(5) & $2800(8)$ & $2903(8)$ & $1516(8)$ & $75(6)$ \\
\hline$C(6)$ & $4245(6)$ & $2972(10)$ & $1161(8)$ & $66(5)$ \\
\hline$C(7)$ & $4708(7)$ & $2685(13)$ & $2304(8)$ & $165(9)$ \\
\hline$C(8)$ & $4585(7)$ & 4095(9) & $1088(10)$ & $145(10)$ \\
\hline$C(9)$ & $3807(6)$ & 1081(8) & $378(9)$ & $52(5)$ \\
\hline $\mathrm{C}(10)$ & $3215(8)$ & $807(10)$ & $-569(10)$ & $68(6)$ \\
\hline$C(11)$ & $2764(9)$ & $-142(13)$ & $-490(12)$ & $100(9)$ \\
\hline$C(12)$ & $3018(9)$ & $-448(10)$ & $452(13)$ & $98(9)$ \\
\hline $\mathbf{C}(1 \mathbf{3})$ & $3669(7)$ & $310(10)$ & $1024(8)$ & $68(6)$ \\
\hline $\mathrm{C}(14)$ & $4483(6)$ & $2007(10)$ & $632(9)$ & $76(6)$ \\
\hline $\mathrm{C}(15)$ & $5395(5)$ & $1529(9)$ & $1070(8)$ & $110(7)$ \\
\hline$\alpha(16)$ & $4475(7)$ & $2548(11)$ & $-351(8)$ & $132(8)$ \\
\hline$C(17)$ & $1549(5)$ & $-244(7)$ & $2508(7)$ & $39(4)$ \\
\hline$C(18)$ & $1461(5)$ & $-805(7)$ & $3262(7)$ & $42(4)$ \\
\hline$C(19)$ & $582(6)$ & $-1208(7)$ & $2946(7)$ & 41(4) \\
\hline$\alpha(20)$ & $166(6)$ & $-896(7)$ & $2003(7)$ & $45(4)$ \\
\hline$C(21)$ & $2275(6)$ & $352(8)$ & 2341(8) & $45(5)$ \\
\hline$C(22)$ & $720(6)$ & $1057(8)$ & $-1219(8)$ & $50(5)$ \\
\hline$C(23)$ & $2866(6)$ & $-1505(9)$ & $4324(7)$ & $78(5)$ \\
\hline$C(24)$ & $71(7)$ & $-2902(8)$ & $3344(8)$ & $89(7)$ \\
\hline
\end{tabular}

a Equivalent isotropic $U$ defined as one-third of the trace of the orthogonalized $U_{i j}$ tensor.
TABLE 8. Atomic coordinates $\left(\times 10^{4}\right)$ and equivalent isotropic displacement coefficients $\left(\mathrm{pm}^{2} \times 10^{-1}\right)$ for complex 9

\begin{tabular}{|c|c|c|c|c|}
\hline & $\bar{x}$ & $y$ & $z$ & $U_{\mathrm{eq}} \overline{\mathrm{a}}$ \\
\hline $\operatorname{Zr}(1)$ & $3051(1)$ & $2216(1)$ & $808(1)$ & $51(1)$ \\
\hline$O(1)$ & $4019(4)$ & 3914(6) & $1577(3)$ & $80(2)$ \\
\hline$O(2)$ & $4390(5)$ & $4340(6)$ & $2916(3)$ & $80(2)$ \\
\hline$O(3)$ & $2817(5)$ & $1519(6)$ & $-542(3)$ & $77(2)$ \\
\hline$O(4)$ & $3934(4)$ & $3402(5)$ & $20(3)$ & $62(2)$ \\
\hline$C(1)$ & $1274(6)$ & $3815(9)$ & $25(5)$ & $67(3)$ \\
\hline$C(2)$ & $899(6)$ & $2328(10)$ & $-87(5)$ & $70(3)$ \\
\hline$C(3)$ & $967(6)$ & $1778(8)$ & $683(5)$ & $66(3)$ \\
\hline $\mathrm{C}(4)$ & $1412(6)$ & $2907(10)$ & $1270(5)$ & $70(3)$ \\
\hline $\mathrm{C}(5)$ & $1583(7)$ & $4165(9)$ & $860(5)$ & $72(4)$ \\
\hline$C(6)$ & $1317(10)$ & $4865(13)$ & $-630(7)$ & $141(7)$ \\
\hline$C(7)$ & $3467(14)$ & $-540(11)$ & $1003(8)$ & $121(7)$ \\
\hline $\mathrm{C}(8)$ & $4533(10)$ & $146(12)$ & $1083(8)$ & $93(5)$ \\
\hline$C(9)$ & $4855(11)$ & $956(15)$ & $1815(10)$ & $135(7)$ \\
\hline$C(10)$ & $4046(14)$ & $756(15)$ & $2128(9)$ & $137(8)$ \\
\hline$\alpha(11)$ & $3146(10)$ & $-113(12)$ & $1660(8)$ & $93(5)$ \\
\hline $\mathrm{C}(12)$ & $2932(16)$ & $-1403(20)$ & $377(9)$ & $299(15)$ \\
\hline$C(13)$ & $4555(6)$ & $4599(8)$ & $2259(4)$ & $55(3)$ \\
\hline$C(14)$ & $3446(6)$ & 2592(8) & $-608(4)$ & $54(3)$ \\
\hline$C(15)$ & $3600(5)$ & $2902(8)$ & $-1423(4)$ & $51(2)$ \\
\hline$C(16)$ & $4405(5)$ & $3993(7)$ & $-1462(3)$ & $47(2)$ \\
\hline$C(17)$ & $4579(5)$ & $4253(7)$ & $-2214(4)$ & $47(2)$ \\
\hline$C(18)$ & $3927(6)$ & $3456(8)$ & $-2921(4)$ & $62(3)$ \\
\hline$C(19)$ & $3117(7)$ & $2424(8)$ & $-2883(4)$ & $74(3)$ \\
\hline$C(20)$ & $2970(6)$ & $2135(9)$ & $-2128(5)$ & $69(3)$ \\
\hline
\end{tabular}

${ }^{a}$ Equivalent isotropic $U$ defined as one-third of the trace of the orthogonalized $U_{i j}$ tensor.

rized in Table 4. Atom coordinates and thermal parameters obtained in this manner for complexes $2,4,7$ and 9 are listed in Tables 5-8.

For the crystals of 4, for which the non-centrosymmetric space group $P 2_{1}$ was determined, we find that the enantiomer represented in Fig. 1 and Table 6 refines to a slightly lower value of $R_{\mathrm{w}}=0.037$ than its mirror image $\left(R_{\mathrm{w}}=0.038\right)$. A Rogers' $\eta$-value of 1.29 \pm 0.26 obtained by this refinement supports the presence of the enantiomer indicated $[28,29]$.

Additional crystallographic data for compounds 2, 4, 7 and 9 are available on request from Fachinformationszentrum Karlsruhe, 7514 Eggenstein-Leopoldshafen 2, upon quotation of deposit number CSD-56826, the authors and the journal reference for this article.

\section{Acknowledgements}

Financial support of this work by VW foundation, by funds of the University of Konstanz and by gifts of chemicals from BASF AG are gratefully acknowledged.

\section{References}

1 R. Leik, L. Zsolnai, G. Huttner, E.W. Neuse and H.H. Brintzinger, J. Organomet. Chem., 312 (1986) 177; M.G. Meirim, 
E.W. Neuse, M. Rhemtula, S. Schmitt and H.H. Brintzinger, Transition Met. Chem., 13 (1988) 272.

2 U. Thewalt and T. Güthner, J. Organomet. Chem., 379 (1989) 59.

3 T. Güthner and U. Thewalt, J. Organomet. Chem., 371 (1989) 43.

4 U. Thewalt and W. Lasser, J. Organomet. Chem., 369 (1989) C12.

5 Z.-Q. Wang, S.-W. Lu, H.-F. Guo, N.-H. Hu und Y.-S. Liu, Polyhedron, 10 (1991) 2341.

6 U. Thewalt and W. Lasser, Z. Naturforsch., $38 b$ (1983) 1501.

7 W. Lasser and U. Thewalt, J. Organomet. Chem., 302 (1986) 201.

8 S. Klima and U. Thewalt, J. Organomet. Chem., 354 (1988) 77.

9 S.I. Bailey, D. Colgan, L.M. Engelhardt, W.P. Leung, R.I. Papasergio, C.L. Raston and A.H. White, J. Chem. Soc., Dalton Trans. (1986) 603.

10 U. Thewalt and T. Güthner, J. Organomet. Chem., 361 (1989) 309.

11 U. Thewalt, S. Klima and K. Berhalter, J. Organomet. Chem., 342 (1988) 303

12 M. Yongxiang, Z. Ying, W. Xin and M. Chunlin, Polyhedron, 8 (1989) 929.

13 Z.-Q. Wang, S.-W. Lu, H.-F. Guo, N.-H. Hu and Y.-S. Liu, Polyhedron, 10 (1991) 2341.

14 Z. Yaokun, W. Zhiqiang, W. Xin and Z. Ying, Polyhedron, 9 (1990) 783.

15 B.N. Diel and H. Hope, Inorg. Chem., 25 (1986) 4448.

16 S. Gutmann, P. Burger, M.-H. Prosenc and H.H. Brintzinger, $J$. Organomet. Chem., 397 (1990) 21.

17 F. Mohamadi and M.M. Spees, Organometallics, 11 (1992) 1398.
18 M.S. Kharasch and O. Reinmuth, Grignard Reactions of Nonmetallic Substances, Prentice Hall, New York, 1954, pp. 948-960.

19 B. Heyn, B. Hipler, G. Keisel, H. Schreer and D. Walther, Anorganische Synthesechemie, Springer-Verlag, Berlin, 1986.

20 E. Samuel and M.D. Rausch, J. Am. Chem. Soc., 95 (1973) 6263; P.C. Wailes, H. Weigold and A.P. Bell, J. Organomet. Chem., 34 (1972) 155.

21 L.T. Reynolds and G. Wilkinson, J. Inorg. Nucl. Chem., 9 (1959) 86.

22 S. Couturier, G. Tainturier and B. Gautheron, J. Organomet. Chem., 195 (1980) 291.

23 H. Schwemlein and H.H. Brintzinger, J. Organomet. Chem., 254 (1983) 69.

24 F.R.W.P. Wild, M. Wasiucionek, G. Huttner and H.H. Brintzinger, J. Organomet. Chem., 288 (1985) 63; S. Collins, B.A. Kuntz, N.J. Taylor and D.G. Ward, J. Organomet. Chem., 342 (1988) 21.

25 R.M. Waymouth, F. Bangerter and P. Pino, Inorg. Chem., 27 (1988) 758; F.R.W.P. Wild, Dissertation, Konstanz, 1983.

26 H. Wiesenfeldt, A. Reinmuth, E. Barsties, K. Evertz and H.H. Brintzinger, J. Organomet. Chem., 369 (1989) 359.

27 P.X. Iten, A.A. Hofmann and C.H. Eugster, Helv. Chim. Acta, 61 (1978) 430.

28 D. Rogers, Acta Crystallogr. Sect. A, 37 (1981) 734; D. Rogers and F.H. Allen, Acta Crystallogr. Sect. B, 35 (1979) 2823.

29 G. Müller, Acta Crystallogr. Sect. B, 44 (1988) 315. 